\title{
Pengaruh Model Pembelajaran Anchored Instruction terhadap Hasil Belajar Siswa
}

\author{
Ravinia N. Sasindua ${ }^{* a}$, Meitij Rampe $^{a}$, Marlina Karundenga
}

a Universitas Negeri Manado, Minahasa, 95618, Indonesia

\begin{tabular}{l} 
I N F O A R T I K E L \\
\hline Diterima 12 Februari 2020 \\
Disetujui 30 Juni 2020 \\
\hline Key word: \\
Anchored Instruction \\
Learning outcomes \\
Mol concept \\
\hline Kata kunci: \\
Anchored Instruction \\
Hasil Belajar \\
Konsep Mol
\end{tabular}

\begin{abstract}
A B S T R A C T
This research is an experimental study using the Anchored Instruction learning model. This study aims to determine the effect of the Anchored Instruction learning model on student learning outcomes on the mole concept subject. This research was conducted in class X SMA Negeri 2 Siau Timur with a sample of 40 people. The research design used was a pre-test and randomized two group design. The experimental class uses the Anchored Instruction learning model and the control class uses the conventional learning model. Analysis of the hypothesis test using $t$-test with a significant level $\alpha=0.05$. The test results obtained indicate that the results of tcount $>$ ttable or 2.112> 2.024, thus $\mathrm{H}_{0}$ is rejected and $\mathrm{H}_{1}$ is accepted, this shows that there is a significant difference between the average value of the initial test (posttest) of the experimental group and the control group. So it can be concluded that there is a difference between student learning outcomes using the Anchored Instruction learning model and student learning outcomes using conventional learning models on mole concept subject.
\end{abstract}

\section{A B STRAK}

Penelitian ini merupakan penelitian eksperimen model pembelajaran Anchored Instruction. Penelitian ini bertujuan untuk mengetahui pengaruh model pembelajaran Anchored Instruction terhadap hasil belajar siswa pada materi konsep mol. Penelitian ini dilaksanakan di kelas X SMA Negeri 2 Siau Timur dengan jumlah sampel 40 orang. Rancangan penelitian yang digunakan adalah pre-test And Poss-test Randomized Two group design. Kelas eksperimen menggunakan model pembelajaran Anchored Instruction dan kelas kontrol menggunakan model pembelajaran konvensional. Analisis uji hipotesis menggunakan uji-t dengan taraf signifikan $\alpha=0,05$. Hasil pengujian yang diperoleh menunjukan bahwa hasil thitung $>$ tabel atau 2,112 $>2,024$, dengan demikian $\mathrm{H}_{0}$ ditolak dan $\mathrm{H}_{1}$ diterima, hal ini menunjukan bahwa terdapat perbedaan signifikan antara rata-rata nilai tes awal (posttest) kelompok eksperimen dan kelompok kontrol. Sehingga dapat disimpulkan bahwa terdapat perbedaan antara hasil belajar siswa yang menggunakan model pembelajaran Anchored Instruction dengan hasil belajar siswa yang menggunakan model pembelajaran konvensional pada materi konsep mol. pembelajaran yang memungkinkan siswa dapat belajar secara aktif dan menyenangkan sehingga siswa dapat meraih hasil belajar dan prestasi yang optimal [1].

Kimia termasuk dalam ilmu yang tidak dapat dimengerti dan dipahami jika hanya dengan membaca teori-teori [2]. Penggunaan model pembelajaran yang tepat dapat mendorong tumbuhnya rasa senang siswa 
terhadap pelajaran, menumbuhkan dan meningkatkan motivasi dalam mengerjakan tugas, memberikan kemudahan bagi siswa untuk memahami pelajaran sehingga memungkinkan siswa mencapai hasil belajar yang lebih baik. Keberhasilan mengajar guru utamanya adalah terletak pada terjadi tidaknya peningkatan hasil belajar siswa, karena itu melalui pemilihan model pembelajaran yang tepat guru dapat memilih atau menyesuaikan jenis pendekatan dan model pembelajaran dengan karakteristik materi pelajaran yang disajikan. Oleh sebab itu guru dituntut untuk memiliki pemahaman yang komprehensif serta mampu mengambil keputusan yang rasional kapan waktu yang tepat untuk menerapkan salah satu atau beberapa strategi secara efektif [3].

Hasil belajar merupakan perubahan perilaku peserta didik akibat belajar. Perubahan itu diupayakan dalam proses belajar mengajar untuk mencapai tujuan pendidikan. Perubahan perilaku disebabkan karena peserta didik mencapai penguasaan atas materi yang diberikan dalam proses belajar mengajar [4]. Berdasarkan hasil observasi dengan cara wawancara pada guru mata pelajaran kimia didapatkan hasil bahwa pada materi konsep mol, hasil belajar siswa masih banyak yang dibawah nilai KKM atau belum tuntas. Wawancara yang juga dilakukan pada siswa kelas X SMA Negeri 2 Siau Timur hasil ditemukan beberapa gejala yang ada, diantaranya adalah a) kurangnya motivasi dan perhatian siswa dalam belajar. Hal ini dapat dibuktikan banyaknya siswa yang terlambat masuk dan ada siswa yang keluar pada jam pelajaran kimia dan hal itu berdampak terhadap rendahnya hasil belajar siswa; b) pada saat memasuki setengah jam pelajaran siswa mulai resah dan ingin cepat-cepat keluar, karena setelah diwawancarai siswa merasa jenuh dengan pelajaran karena tidak ada aktifitas yang dilakukan selain mencatat dan mendengar; dan c) Guru lebih sering menggunakan metode ceramah dalam pembelajaran kimia sehingga siswa lebih memilih aktifitas lain dalam kelas dan banyak siswa yang mengantuk ketika pembelajaran berlangsung. Hasil wawancara diatas dibuktikan dengan rendahnya hasil belajar kimia di semester satu pada siswa kelas X SMA Negeri 2 Siau Timur. Hal ini terlihat dari nilai hasil evaluasi belajar dengan nilai KKM 75, sebagian besar siswa tidak tuntas. hanya terdapat 19 (47,5\%) siswa yang tuntas dengan memiliki nilai KKM lebih dari 75 dan sisanya 21 $(52,5 \%)$ siswa tidak tuntas atau nilai KKM kurang dari 75 .

Rendahnya hasil belajar pada materi konsep mol sebagai dasar perhitungan kimia siswa tersebut kemungkinan karena kurangnya pemahaman siswa terhadap konsep-konsep dari materi yang diajarkan. Selain itu, guru lebih sering menggunakan metode ceramah dalam pembelajaran, sehingga siswa hanya sebatas mendengarkan, memperhatikan materi pelajaran yang diterangkan serta mengerjakan tugas yang diberikan oleh guru [5]. Pembelajaran seperti ini dapat membatasi siswa dalam menuangkan ide, gagasan dan kreatifitas siswa dalam pembelajaran. keadaan ini menyebabkan siswa lebih cepat bosan dalam mengikuti proses belajar mengajar sehingga dapat menyebabkan hasil belajar siswa menjadi rendah. Untuk mengatasi masalah tersebut diharapkan guru dapat memilih model yang tepat dalam kegiatan pembelajaran, sehingga siswa dapat dengan aktif dalam belajar serta tujuan pendidikan dapat tercapai [6]. Hal ini dapat dilakukan dengan cara penerapan pembelajaran yang tidak lagi berpusat pada guru, tetapi lebih menjadikan guru sebagai fasilitator. Salah satu model pembelajaran yang dirasa tepat untuk diterapkan yaitu model pembelajaran Anchored Instruction.

Model pembelajaran Anchored dikembangkan dan melibatkan rancangan yang khusus, berdasarkan videobased format yang disebut "anchor" atau "kasus" yang memberikan dasar untuk eksplorasi dan kolaborasi dalam memecahkan masalah. Cerita dalam video menggambarkan kehidupan nyata yang dapat dieksplorasi diberbagai tingkatan [7]. Video tersebut dirancang untuk memungkinkan guru serta siswa untuk menghubungkan pengetahuan matematika dengan pelajaran lainnya dengan menjelajahi lingkungan dari sudut pandang yang berbeda [8].

Model pembelajaran Anchored merupakan model pembelajaran berbasis masalah, akan tetapi model pembelajaran Anchored lebih 
banyak menggunakan media pembelajaran [9]. Dengan demikian, siswa dapat bekerja secara mandiri, walaupun tidak lepas dari bimbingan guru. Terlebih lagi, permasalahan yang akan dikerjakan oleh siswa berbentuk cerita sehingga siswatidak akan merasa bosan selama mengikuti proses belajarmengajar. Model pembelajaran ini meliputi penyimpulan informasi sekitar permasalahan yang ada, melakukan sintesis dan merepresentasikan apa yang didapat dari orang lain [10].

Model pembelajaran Anchored memiliki beberapa keuntungan dibandingkan model pembelajaran lain. Keuntungan tersebut antara lain siswa dapat menjadi pemecah masalah sendiri, mengembangkan pemahaman secara mendalam, meningkatkan kemungkinan untuk mentransfer pengetahuan pada situasi yang berbeda, meningkatkan kemampuan kolaboratif, kooperatif dan negosiasi siswa. Pembelajaran menjadi lebih efektif ketika guru menggunakan multimedia dapat berupa powerpoint untuk menghubungkan teori kognitif yang dimiliki siswa dengan lingkungan pembelajaran berbasis masalah dibandingkan pembelajaran secara tradisional. Penggunaan web sebagai salah satu bantuan dalam pembelajaran Anchored juga memberikan hasil yang positif dalam peningkatan potensial siswa dalam memahami konsep pelajaran, memecahkan masalah serta penggunaan waktu dalam perencanaan pemecahan masalah [11-13].

Penelitian ini merupakan penelitian eksperimen model pembelajaran yang bertujuan untuk mengetahui pengaruh hasil belajar siswa yang yang menggunakan model pembelajaran Anchored Instruction dan dengan siswa yang mengikuti Pembelajaran konvensional terhadap peningkatan hasil belajar materi konsep mol pada siswa kelas $X$ SMA Negeri 2 Siau Timur

\section{Metode}

Model penelitian ini adalah penelitian eksperimen. Rancangan penelitian yang digunakan dalam penelitian ini adalah "pre-test And Poss-test Randomized Two group design" seperti yang dipaparkan dalam tabel 1 .

Dimana E adalah kelompok eksperimen yang diajar dengan model pembelajaran anchored instruction, P adalah Kelompok Kontrol tidak diajar dengan metode ceramah, $\mathrm{Y}_{1}$ adalah tes awal untuk dua kelompok, $\mathrm{Y}_{2}$ adalah tes akhir untuk dua kelompok, $\mathrm{X}$ adalah perlakuan dan ${ }^{\circledR}$ artinya acak.

Tabel 1. Rancangan penelitian.

\begin{tabular}{cccc}
\hline Kelompok & Pre-Test & Treatment & $\begin{array}{c}\text { Post- } \\
\text { Test }\end{array}$ \\
\hline$\circledR E$ & $\mathrm{Y}_{1}$ & $\mathrm{X}$ & $\mathrm{Y}_{2}$ \\
$\circledR \mathrm{P}$ & $\mathrm{Y}_{1}$ & - & $\mathrm{Y}_{2}$ \\
\hline
\end{tabular}

\section{Hasil dan Pembahasan}

Deskripsi Statistik

Tabel 2. Deskripsi statistik data kelas

\begin{tabular}{|c|c|c|c|}
\hline \multicolumn{4}{|c|}{ Statistics } \\
\hline & & PRETEST & POSTTEST \\
\hline \multirow{2}{*}{$\mathrm{N}$} & Valid & 20 & 20 \\
\hline & Missing & 0 & 0 \\
\hline $\mathrm{Me}$ & & 69,00 & 82,75 \\
\hline $\mathrm{Me}$ & & 70,00 & 82,50 \\
\hline $\mathrm{Mc}$ & & 75 & $80^{a}$ \\
\hline Stc & tion & 7,712 & 6,973 \\
\hline $\mathrm{Va}$ & & 59,474 & 48,618 \\
\hline $\mathrm{Ra}$ & & 25 & 25 \\
\hline Mi & & 55 & 70 \\
\hline $\mathrm{Ma}$ & & 80 & 95 \\
\hline Su & & 1380 & 1655 \\
\hline
\end{tabular}

Deskripsi Data Hasil Belajar Kelas eksperimen ditunjukkan dalam tabel 2. Data hasil belajar kelas eksperimen $X_{a}$ SMA Negeri 2 Siau Timur setelah menggunakan model pembelajaran Anchored Instruction menunjukan bahwa skor tertinggi adalah 95 sedangkan skor terendah adalah 70 . Berdasarkan data tersebut didapatkan harga modus 80, median 82,50, mean 82,75, varians 43,355. Selanjutnya berdasarkan hasil akhir yang diperoleh oleh siswa (posttest) maka dapat dibuat tabel distribusi frekuensi pada tabel 3.

Deskripsi data hasil belajar kelas kontrol ditunjukkan pada tabel 4. Data hasil belajar variabel kelas kontrol yaitu $\mathrm{X}_{\mathrm{b}}$ SMA Negeri 2 Siau Timur dengan menggunakan model pembelajaran konvensional menunjukan bahwa skor tertinggi adalah 70 sedangkan skor terendah adalah 90. Berdasarkan data tersebut 
didapatkan harga modus 80, median 80,00, mean 78,50, varians 39,737 Berdasarkan hasil yang diperoleh oleh siswa maka dapat dibuat tabel distribusi frekuensi pada tabel 5 .

Tabel 3. Distribusi Frekuensi hasil Postest pada kelas eksperimen.

\begin{tabular}{|c|c|c|c|c|c|}
\hline \multicolumn{6}{|c|}{ POSTTEST } \\
\hline & & $\begin{array}{c}\text { Frequ } \\
\text { ency }\end{array}$ & $\begin{array}{c}\text { Perc } \\
\text { ent }\end{array}$ & $\begin{array}{c}\text { Vali } \\
\mathrm{d} \\
\text { Perc } \\
\text { ent }\end{array}$ & $\begin{array}{c}\text { Cumul } \\
\text { ative } \\
\text { Percent }\end{array}$ \\
\hline & 70 & 1 & 5,0 & 5,0 & 5,0 \\
\hline & 75 & 4 & 20,0 & 20,0 & 25,0 \\
\hline & 80 & 5 & 25,0 & 25,0 & 50,0 \\
\hline $\mathrm{Va}$ & 85 & 5 & 25,0 & 25,0 & 75,0 \\
\hline lid & 90 & 3 & 15,0 & 15,0 & 90,0 \\
\hline & 95 & 2 & 10,0 & 10,0 & 100,0 \\
\hline & $\begin{array}{l}\text { To } \\
\text { tal }\end{array}$ & 20 & $\begin{array}{c}100 \\
0\end{array}$ & $\begin{array}{c}100 \\
0\end{array}$ & \\
\hline
\end{tabular}

Tabel 4. Data hasil belajar kelas kontrol

\begin{tabular}{|c|c|c|c|}
\hline \multicolumn{4}{|c|}{ Statistics } \\
\hline & & PRETEST & POSTTEST \\
\hline \multirow{2}{*}{$\mathrm{N}$} & Valid & 20 & 20 \\
\hline & Missing & 0 & 0 \\
\hline \multicolumn{2}{|c|}{ Mean } & 64,75 & 78,50 \\
\hline \multicolumn{2}{|c|}{ Median } & 65,00 & 80,00 \\
\hline \multicolumn{2}{|c|}{ Mode } & 75 & 80 \\
\hline \multicolumn{2}{|c|}{ Std. Deviation } & 8,807 & 6,304 \\
\hline \multicolumn{2}{|c|}{ Variance } & 77,566 & 39,737 \\
\hline \multicolumn{2}{|c|}{ Range } & 25 & 20 \\
\hline \multicolumn{2}{|c|}{ Minimum } & 50 & 70 \\
\hline \multicolumn{2}{|c|}{ Maximum } & 75 & 90 \\
\hline \multicolumn{2}{|c|}{ Sum } & 1295 & 1570 \\
\hline
\end{tabular}

Tabel 5. Distribusi Frekuensi hasil Postest

\begin{tabular}{|c|c|c|c|c|c|}
\hline \multicolumn{6}{|c|}{ POSTTEST } \\
\hline & & $\begin{array}{l}\text { Frequ } \\
\text { ency }\end{array}$ & $\begin{array}{c}\text { Perc } \\
\text { ent }\end{array}$ & $\begin{array}{c}\text { Vali } \\
\mathrm{d} \\
\text { Perc } \\
\text { ent }\end{array}$ & $\begin{array}{l}\text { Cumul } \\
\text { ative } \\
\text { Percent }\end{array}$ \\
\hline \multirow{6}{*}{$\begin{array}{l}\text { Va } \\
\text { lid }\end{array}$} & 70 & 4 & 20,0 & 20,0 & 20,0 \\
\hline & 75 & 5 & 25,0 & 25,0 & 45,0 \\
\hline & 80 & 6 & 30,0 & 30,0 & 75,0 \\
\hline & 85 & 3 & 15,0 & 15,0 & 90,0 \\
\hline & 90 & 2 & 10,0 & 10,0 & 100,0 \\
\hline & $\begin{array}{l}\text { To } \\
\text { tal }\end{array}$ & 20 & $\begin{array}{c}100 \\
0\end{array}$ & $\begin{array}{c}100 \\
0\end{array}$ & \\
\hline
\end{tabular}

\section{Uji Normalitas}

Pengujian normalitas adalah untuk melihat sebaran data suatu variabel normal atau tidak, yang dilakukan dengan uji liliefors. Kriteria uji normalitas adalah $\mathrm{H}_{0}$ ditolak jika Lhitung lebih besar dari Ltabel, dan $\mathrm{H}_{0}$ diterima jika Lhitung lebih kecil dari Ltabel
Uji normalitas tes awal (pre-test).

Dari tabel 6 uji normalitas hasil tes awal diperoleh Lhitung $=0,148$, dan Lhitung $=0,127$ sedangkan Ltabel $=20$, dengan $\alpha=0,05$ adalah 0,195 , karena Lhitung < Ltabel maka $\mathrm{H}_{0}$ yang menyatakan bahwa populasi berdistribusi normal atau diterima.

Tabel 6. Uji Normalitas data Pre-test kelas eksperimen dan Kelas Kelas kontrol

\begin{tabular}{|c|c|c|c|c|}
\hline & \multicolumn{2}{|c|}{ Lhitung } & Ltabel & Kesimpulan \\
\hline $\mathrm{N}$ & Eksperimen & Kontrol & & \\
\hline 20 & 0,148 & 0,127 & 0,195 & Normal \\
\hline
\end{tabular}

Uji Normalitas hasil tes akhir (post test)

Dari tabel 7 uji normalitas hasil tes awal diperoleh Lhitung $=0,153$ dan Lhitung $=0,160$ sedangkan Ltabel $=20$, dengan $\alpha=0,05$ adalah , karena Lhitung $<$ Ltabel maka Ho yang menyatakan bahwa populasi berdistribusi normal atau diterima.

Tabel 7. Uji Normalitas Data Post-test Kelas eksperimen dan Kelas Kelas kontrol

\begin{tabular}{|c|c|c|c|c|}
\hline & \multicolumn{2}{|c|}{ Lhitung } & Ltabel & Kesimpulan \\
\hline $\mathrm{N}$ & Eksperimen & Kontrol & & \\
\hline 20 & 0,153 & 0,160 & 0,195 & Normal \\
\hline
\end{tabular}

Uji Homogenitas

Uji Homogenitas varians, dilakukan menggunakan uji $\mathrm{F}$ (Fisher). Kriteria homogenitas adalah $\mathrm{H}_{0}$ ditolak jika fhitung lebih besar dari ftabel dan $\mathrm{H}_{0}$ terima jika fnitung lebih kecil dari ftabel. Dengan diterimanya $\mathrm{H}_{0}$ berarti sampel kelompok eksperimen dan kelompok kontrol homogen.

\section{Uji homogenitas pre-test}

Hasil analisis pengujian homogenitas varian pada data tes awal (pretest) kelas eksperimen dan kontrol dengan $\mathrm{Vb}=77,566$ dan $\mathrm{Vk}=59,474$ memberikan fhitung $=1,304$ sedangka untuk ftabel $=2,525\left(\mathrm{db}_{\text {pembilang }}=\mathrm{n} 1-1=20-1=19\right.$ dan $\left.d b_{\text {penyebut }}=\mathrm{n} 2-1=20-1=19\right)$. Hasil ini menunjukan bahwa fhitung $<\mathrm{f}_{\text {tabel }}$ atau fhitung $=1,304<\mathrm{f}_{\text {tabel }}=2,525$ 
sehingga $\mathrm{H}_{0}$ dapat diterima. Jadi varians dari tes awal (pretest) adalah homogen.Hasil ini ditunjukkan dalam tabel 8 .

Tabel 8. Uji homogenitas pre-test

\begin{tabular}{cccccc}
\hline $\mathrm{N}$ & \multicolumn{2}{c}{ Variaans } & Fhitung & Ftabel & $\begin{array}{c}\text { Kesimpu- } \\
\text { lan }\end{array}$ \\
& Eksperimen Kontrol & & & \\
\hline 20 & 59,474 & 77,566 & 1,304 & 2,525 & Homogen \\
\hline
\end{tabular}

Uji homogenitas post-test

Hasil analisis pengujian homogenitas varian pada data tes akhir (postest) kelas eksperimen dan kontrol dengan $\mathrm{Vb}=48,618$ dan $\mathrm{Vk}=39,737$ memberikan fhitung $=1,223$ sedangka untuk ftabel $=2,525\left(\mathrm{db}_{\text {pembilang }}=\mathrm{n1}-1=20-1=19\right.$ dan $\left.\mathrm{db}_{\text {penyebut }}=\mathrm{n} 2-1=20-1=19\right)$. Hasil ini menunjukan bahwa $f_{\text {hitung }}<\mathrm{f}_{\text {tabel }}$ atau fhitung $=1,223<\mathrm{f}_{\text {tabel }}=2,525$ sehingga $\mathrm{H}_{0}$ dapat diterima. Hasil ini ditunjukkan pada tabel 9. Jadi varians dari tes akhir (posttest) adalah homogen.

Tabel 9. Uji homogenitas post-test

\begin{tabular}{cccccc}
\hline $\mathrm{N}$ & \multicolumn{2}{c}{ Variaans } & Fhitun & Ftabel & Kesimpula \\
& $\begin{array}{c}\text { Eksperime } \\
\mathrm{n}\end{array}$ & $\begin{array}{c}\text { Kontro } \\
1\end{array}$ & $\mathrm{~g}$ & & $\mathrm{n}$ \\
& & & & & \\
\hline 20 & 48,618 & 39,737 & 1,223 & 2,525 & Homogen \\
\hline
\end{tabular}

\section{Uji Hipotesis}

Setelah dilakukan uji prasyarat analisi data, diketahui bahwa data hasil belajar kedua kelas pada penelitian ini berdistribusi normal dan homogen, sehingga pengujian data hasil belajar kedua kelas dilanjutkan pada analisis data berikutnya, yaitu uji hipotesis menggunakan uji-t yang hasilnya ditunjukkan dalam tabel 10 . Berdasarkan hasil perhitungan, diperoleh tabel pengujian hipotesis data hasil belajar.

Tabel 10. Uji hipotesis

\begin{tabular}{ccc}
\hline Statistik & Pretest & Posttest \\
& & \\
$\mathrm{N}$ & 20 & 20 \\
$\mathrm{X}_{1}$ & 69,00 & 82,75 \\
$\mathrm{X}_{2}$ & 64,75 & 78,50 \\
$\mathrm{~S}_{1}{ }^{2}$ & 59,474 & 48,618 \\
$\mathrm{~S}_{2}{ }^{2}$ & 77,566 & 35,737 \\
$\mathrm{~L}_{\text {tabel }}$ & 2,024 & 2,024 \\
Lhitung & 1,66 & 2,112 \\
Kesimpulan & H1 diterima & Hoditolak \\
\hline
\end{tabular}

Dari hasil pengujian hipotesis data tes awal, pada taraf nyata $\alpha=0,05$ diperoleh thitung $=$
1.66 dan tabel $=4.10$ Hasil pengujian yang dipeoleh menunjukan bahwa hasil thitung $<$ tabel atau $1,66<4.10$, dengan demikian $\mathrm{H}_{0}$ diterima dan $\mathrm{H}_{1}$ ditolak hal ini menunjukan bahwa tidak terdapat perbedaan signifikan antara rata-rata nilai tes awal (pre-test) kelompok eksperimen dan kelompok kontrol.

Dari hasil pengujian hipotesis data tes akhir, pada taraf nyata $\alpha=0,05$ diperoleh thitung $=$ 2,112 dan tabel $=2,024$. Hasil pengujian yang diperoleh menunjukan bahwa hasil thitung $>$ tabel atau 2,112 > 2,024, dengan demikian $\mathrm{H}_{0}$ ditolak dan $\mathrm{H}_{1}$ diterima hal ini menunjukan bahwa terdapat perbedaan signifikan antara rata-rata nilai tes awal (post-test) kelompok eksperimen dan kelompok kontrol.

\section{Pembahasan}

Berdasarkan uji hipotesis dari pretest dan posttest kedua kelas dapat dilihat bahwa pada pengujian hipotesis pretest $\mathrm{H}_{0}$ diterima dengan hipotesi pengujian $\mathrm{H}_{0}: \mu_{1} \mu_{2}$ ini berarti rata-rata hasil belajar siswa pada pretest sama atau tidak terdapat perbedaan yang signifikan antara ratarata nilai tes awal (pretest) kelompok eksperimen dan kelompok kontrol. Sedangkan pada pengujian hipotesis posttest $\mathrm{H}_{0}$ ditolak dengan pengujian $\mathrm{H}_{1}: \mu_{1} \mu_{2}$ ini berarti bahwa kedua rata-rata hasil belajar posttest memiliki daya tekan berbeda atau terdapat perbedaan signifikan antara rata-rata nilai tes awal (posttest) kelompok eksperimen dan kelompok kontrol. Hal ini disebabkan karena adanya perlakuan atau eksperimen yang diberikan sesudah diberikan pretest berupa penggunaan model anchored instruction dalam pembelajaran konsep mol. Sehingga pada pengujian hipotesis posttest terlihat adanya perbedaan hasil belajar siswa yang diajarkan memakai model pembelajaran anchored instruction

Statistik uji-t posttest diperoleh bahwa thitung $=>$ tabel $=2,112$, sehingga tolak $\mathrm{H}_{0}$ dan terima $\mathrm{H}_{1}$. Dengan demikian dapat disimpulkan bahwa hipotesis yang diajukan diterima yaitu: Terdapat pengaruh terhadap hasil belajar siswa yang mengikuti pembelajaran dengan model anchored instruction dibandingkan dengan siswa yang mengikuti pembelajaran konvensional pada mata pelajaran kimia materi konsep MOL. 


\section{Kesimpulan}

Terdapat pengaruh terhadap hasil belajar siswa yang mengikuti pembelajaran dengan menggunakan model anchored instruction dibandingkan dengan siswa yang mengikuti pembelajaran konvensional pada mata pelajaran Kimia khusunya materi konsep mol siswa kelas X SMA Negeri 2 Siau Timur. Pengaruh yang diberikan dapat dilihat pada hasil pengujian pretest dan posttest. Berdasarkan gambaran tersebut dapat disimpulkan bahwa penggunaan model anchored instruction telah memberikan pengaruh yang signifikan terhadap hasil belajar siswa kelas X SMA Negeri 2 Siau Timur.

\section{Daftar Pustaka}

1. Cahyati, I.; Kuntadi, D.; Mulhayatiah, D. Penerapan Model Pembelajaran Anchored Instruction untuk Meningkatkan Kemampuan Pemecahan Masalah Peserta Didik pada Materi Kalor. J. Teach. Learn. Phys. 2019, 1, 19-23, doi:10.15575/jotalp.v1i1.3434.

2. Tahulending, A.W.; Rumampuk, R.; Aloanis, A.A. Pengembangan Penuntun Praktikum Reaksi Reduksi dan Oksidasi Berbasis Bahan Alam dengan Menggunakan Model ADDIE. Oxyg. J. Chem. Educ. 2019, 1, 61-65.

3. Thomas, C.N.; Rieth, H.J. A Research Synthesis of the Literature on Multimedia Anchored Instruction in Preservice Teacher Education. J. Spec. Educ. Technol. 2011, 26, 1-22, doi:10.1177/016264341102600201.

4. Lumentut, R.S.; Said, I.; Mustapa, K. Pengaruh model pembelajaran guided inquiry dengan mind map terhadap hasil belajar dan motivasi siswa pada materi redoks di kelas X SMA Negeri 5 Palu. J. Akad. Kim. 2017, 6, 113-118.

5. Kellogg, M. Preservice Elementary Teachers $^{\text {ee }} \quad$ Pedagogical Content Knowledge Related to Area and Perimeter: A Teacher Development Experiment Investigating Anchored Instruction With Web-Based Microworlds, University of South Florida: Florida, 2010.

6. Hochholdinger, S.; Schaper, N. Training troubleshooting skills with an anchored instruction module in an authentic computer based simulation environment. J. Tech. Educ. 2013, 1, 7-22.

7. Kissinger, J.; Kissinger, J.; Cao, R.; Sierra, K.; Hilpot, J. Harnessing Anchored Instruction In Blended Language Courses With VoiceThread. E-Learn World Conf. ELearning Corp. Gov. Heal. 2017, 2017, 373379.

8. Ariyanto, L. Pengembangan Perangkat Pembelajaran Matematika Model Berjangkar (Anchored Instruction) Materi Luas Kubus dan Balok Kelas VIII. AKSIOMA J. Mat. dan Pendidik. Mat. 2011, 2, doi:10.26877/AKS.V2I2/SEPTEMBE.39.

9. Duncan, G.W.; Bamberry, G. Anchored Instruction: Its Potential for Teaching Introductory Management. Int. J. Learn. 2010, 17, 163-177.

10. Bottge, B.A.; Toland, M.D.; Gassaway, L.; Butler, M.; Choo, S.; Griffen, A.K.; Ma, X. Impact of Enhanced Anchored Instruction in Inclusive Math Classrooms. Except. Child. 2015, 81, 158-175, doi:10.1177/0014402914551742.

11. Kuntadi, D.; Ghautama, H.L.G. Penerapan Model Pembelajaran Anchored Instruction untuk Meningkatkan Kemampuan Pemecahan Masalah Peserta Didik. J. Teach. Learn. Phys. 2019, 1, 13-18, doi:10.15575/jotalp.v1i1.3433.

12. Hafizah, E.; Hidayat, A.; -, M. Pengaruh Model Pembelajaran Anchored Instruction terhadap Penguasaan Konsep dan Kemampuan Pemecahan Masalah Fisika Siswa Kelas X. J. Fis. Indones. 2015, 18, 8-12, doi:10.22146/jfi.24396.

13. Costillas, J.M. Extent of Transfer of Problem Solving Skills to Other Domains Facilitated Through Anchored Instruction. J. Educ. Hum. Resour. Dev. 2015, 3, 1-23. 